\title{
Article
}

\section{The use of self-reflection for enhanced enterprise education: a case study}

Clarke, Andy, Ferry, Natalie and Clare, Cornes

Available at http://clok.uclan.ac.uk/34074/

Clarke, Andy ORCID: 0000-0003-4291-9851, Ferry, Natalie and Clare, Cornes (2020) The use of self-reflection for enhanced enterprise education: a case study. Education and Training . ISSN 0040-0912

It is advisable to refer to the publisher's version if you intend to cite from the work. http://dx.doi.org/10.1108/ET-03-2019-0050

For more information about UCLan's research in this area go to

http://www.uclan.ac.uk/researchgroups/ and search for < name of research Group>.

For information about Research generally at UCLan please go to http://www.uclan.ac.uk/research/

All outputs in CLoK are protected by Intellectual Property Rights law, including Copyright law. Copyright, IPR and Moral Rights for the works on this site are retained by the individual authors and/or other copyright owners. Terms and conditions for use of this material are defined in the policies page.

\section{CLoK}

Central Lancashire online Knowledge www.clok.uclan.ac.uk

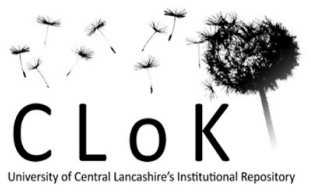




\title{
The use of self-reflection for enhanced enterprise education: a case study
}

\begin{abstract}
Purpose

A case study was undertaken to evaluate the use of self-reflection in enterprise education in a UK university, where the taught content was tailored to ensure relevance to the students who were from a variety of subject disciplines.

Design/Methodology

Enterprise taught content was established in masters level 7 programmes across a range of subject disciplines. Taught content was designed using problem based learning, and evaluated using self-reflective methodologies. The paper reflects on the current position of enterprise education and asks the research question of whether the use of self-reflective teaching methodologies are valid for enterprise education.
\end{abstract}

\section{Findings}

Results suggest that the students appreciated the introduction of enterprise into their course and in the main did not view it as disjointed or irrelevant to their wider aims. More so, the students commented favourably towards the integration of enterprise into their primary discipline, and noted an enhanced learning experience because of this integration.

\section{Research Limitations/Implications}

For the University: A novel approach to enterprise teaching has been developed at a UK university, focusing on teaching non-business students how to be more valuable to a business within their degree subject context. This has empowered the students with an enhanced understanding of commercial issues and increased employability (Rae 2007, Huq and Gilbert 2017). This has also led to enhanced relationships with industry and given students a wider understanding of their degree area.

\section{Practical Implications}

For the educator: The use of self-reflective teaching methodologies (Hayward, 2000) are noted to be vital in order to deliver enterprise education in a way that is relevant to the student cohort body. By reflecting on ones teaching style and delivery method, the authors were able to engage non-business students in enterprise education, and receive a high level of student satisfaction. It is noted that self-reflection was a valuable process for delivery to each degree discipline. By employing problem based learning and self-reflective teaching methodologies, an increased synergy between the business taught elements and the science subjects was created.

\section{Originality/Value}

This approach is shown to empower the students with an enhanced understanding of commercial issues and an increased employability. This has led to enhanced relationships between academia and industry, and given students a wider understanding of their degree area; the enhanced relationships with industry offer students a wider commercial understanding of their degree area.

A gap in the current knowledge base in enterprise education has been identified: enterprise education with the aim of educating the student to be more valuable to a business as opposed to starting a business. The use of self-reflective methodologies has offered a novel approach to enterprise teaching in a UK university.

\section{Keywords}


enterprise education; enterprise educators; student enterprise; employability; commercial awareness

\section{Introduction and Background}

This paper discusses the aim of making enterprise education more relevant to nonbusiness students in a UK university. The paper identifies a current gap in the knowledge base where entrepreneurship education is delivered when enterprise education may be more appropriate (Penaluna, 2013), and it discusses the development of a novel approach to enterprise education within the science disciplines using problem based learning (PBL) and self-reflective teaching (Hayward, 2000), and how that approach enabled the student body to be more valuable to the company that they will work for, and not to teach them how to start a company. The paper sets the current context of enterprise education in the Higher Education sector, and discusses the definitions and role of enterprise education within universities. The paper continues to review pedagogical styles relating to enterprise and entrepreneurship teaching, noting the QAA definitions of both. The paper discusses appropriate enterprise teaching methods and reviews the results of those using a case study methodology. The paper reflects on the current position of enterprise education and asks the research question of whether the use of self-reflective teaching methodologies are valid for enterprise education. This research question allows the analysis and discussion of student feedback data using simple null hypothesis approach, where the $p$ value is measured from the data collected from the student surveys, aiming to reduce introduction of inflated $p$ values (Meyer et al., 2017).

\section{Literature Review}

\section{Socio-Political context}

The contribution to a nation's economy and society that entrepreneurs provide is widely accepted; the SMEs that are created help drive economic growth an contribute to job creation (Williams et al., 2015). The value of enterprise and entrepreneurship is recognised in the Europe 2020 Strategy (European Commission, 2010); in the recommendations for developing key competencies for life-long learning, the EU recognises eight key competences that are 'crucial to better prepare people for today's societies'. Promoting entrepreneurial education is key, with the competency of: 'Entrepreneurship - enhancing entrepreneurial attitudes to unlock personal potential, creativity and self-initiative' (European Commission, 2018). In a report in 2014, Young (2014) states that 'enterprise means more than just the ability to become an entrepreneur. It is that quality that gives an individual a positive outlook, an ability to see the glass as half full rather than half empty, and is a valuable attribute for the whole of life.' Young continues to note that all university students should have access to enterprise and entrepreneurship, and enterprise education should extend to all areas of faculty and study (Young, 2014). Young states that universities are perfectly placed to engage and support entrepreneurship amongst students due to the industrial backgrounds of the teaching staff, combined with the world-class facilities and the relationships with businesses (Young, 2014). In the report Young (2014) notes that students of all subjects have access to enterprise modules, and those modules should not be confined to students who attend business schools.

Taking the QAA (2018) definitions:

- Enterprise: the generation and application of ideas, which are set within practical situations during a project or undertaking. This is a generic concept that can be applied across all areas of education and professional life. 
- Entrepreneurship: the application of enterprise behaviours, attributes and competencies into the creation of cultural, social or economic value. This can, but does not exclusively, lead to venture creation.

This paper offers a case study of students from a range of subject areas, focusing on how to make those students more valuable to the business that they will work for, as opposed to making them more able to start their own business; from the QAA definitions thereby teaching enterprise and not entrepreneurship. This aligns to Jones and Penaluna (2013), who state that only around $10 \%$ of students engage in start-up activities on completion of their studies. However the authors acknowledge that the terms enterprise and entrepreneurship are widely interchanged in use. This approach was taken as to teach enterprise would engage $90 \%$ of the student body, and to teach entrepreneurship would engage $10 \%$ of the student body.

The Researcher Development Framework (Vitae, 2010) states that employers in the scientific sector are looking for researchers with a level of commercial acumen, noting factors such as 'engages in the commercialisation of intellectual property where appropriate; commercially and socially aware; develops a deeper commercial awareness; highly skilled at developing relationships in business/commercial context; recognises potential for new products and novel applications of research for commercial and/or social benefit'. Bray and Boon (2011) evaluate this framework in the context of its use in facilitating career development in researchers in the UK. Bray and Boon (2011) support the use of the Vitae framework, noting a move away from traditionalist approaches of matching individuals to jobs based on their objective characteristics, and moving to a less linear, more dynamic approach where individual characteristics are replaced by individual aspirations. The Department of Business and Innovation states that: ...continued strong demand for graduates will rest on whether they are actually perceived as high quality in intellectual terms, but even more importantly whether they have the communication and people skills plus positive work and commercial attitudes, which were the 'must have' behaviours for employers. Understanding of, and interest in business was especially important to small firms (Pollard et al., 2015). This paper argues that the dynamic approach and the need for graduates with an interest in business and positive commercial attitudes requires a novel teaching and learning framework and a novel approach to enterprise education.

The value of entrepreneurship education at university, and the challenges faced by that is well established (Fayolle et al., 2006; Matlay and Carey, 2007; Matlay, 2008; Rae, 2007; Rae and Matlay, 2010; Rae et al., 2014). The following sections detail entrepreneurship and enterprise in education, in relation to Higher Education Institutes (HEIs).

What is enterprise in relation to university teaching?

Investigations into the impact education of enterprise in HEls has on the quality of graduate business start-ups are many, but relatively difficult to compare as the parameters for each are so different. However, a study focusing on the Hunter Centre for Entrepreneurship, University of Strathclyde was conducted by Galloway and Brown (2011) to shed light on the impact of such education on students. The study used two sample groups and considers the difference between students who have studied entrepreneurship in at least one of the Hunter Centre modules and those that have not. Numerous barriers to successful entrepreneurship in universities were identified in this study, including: the type of entrepreneurship education delivered; the prevailing culture and expectation of entrepreneurship; the economic climate; the negative image of entrepreneurs in society; demand for the creation of entrepreneurs et cetera (Galloway and Brown, 2002). However, it was also noted that the key to improving perceptions and attitudes towards entrepreneurship is education (Galloway \& Brown, 2002). Following on from this, it was identified that the number of graduate start-up companies cannot define the role of 
entrepreneurship education in HE; entrepreneurship education is also a contributor to the quality of those start-ups and the attitude towards entrepreneurship. It has become clear that the return of entrepreneurship education is a long-term strategy rather than a short or medium term one, thus the potential growth is the measure of entrepreneurial education as opposed to measuring the number of immediate start-up companies (Galloway \& Brown, 2002; McKeown et al., 2006).

Mwasalwiba (2010) found that although there is no consensus in the basic definitions of entrepreneurial education, there is a general understanding of what entrepreneurship education is trying to achieve; that being to promote entrepreneurship by influencing attitudes, values and culture. Mwasalwiba (2010) also argues that, in agreement with Jones and Penaluna (2013), not all students who join an entrepreneurship programme intend to start a business. Mwasalwiba (2010) states that further research on the performance of entrepreneurship graduates in the workplace is therefore needed.

Similarly, the value of subject specific entrepreneurship programmes requires further research (Mosly, 2017). In 2017, Mosly investigated the influence of the perception of students on their future career direction, and the openness of those students to change, noting that 'the majority of study participants seek to establish their own business in the future'. Mosly (2017) goes on to state that $90 \%$ of participants recorded that the programme enabled them to be better placed to do that. This study is one of many that demonstrate inconsistency amongst HEls. For example, Ghandi's et al. (2016) review of entrepreneurship education in engineering programmes identified that universities in the United States offered education of this type through business schools. This resulted in students understanding the business aspect, but not in relation to their primary subject. This is echoed by Penaluna et al. (2012) and Lautenschläger et al. (2011) who questioned the efficacy and appropriateness of current entrepreneurial and enterprise teaching. Lautenschläger et al. (2011) noted that the stimulation of creative thinking, instead of teaching knowledge on business creation, created a problem-solving mindset. Lautenschläger et al. (2011) continued to note that the particular characteristics of an entrepreneur do not rely on specialist knowledge on how to start a business, but in the abilities of how to attract resources, develop ideas, to be able to follow a vision. The traits of being proactive, creative and innovative are noted as the features of an entrepreneur. In order to realise this, Lautenschläger et al. (2011) state that the educational system should concentrate on nurturing creativity as well as critical thinking. A necessary change in teaching methods is noted, which also concurs with Alberti et al. (2004), Jones et al. (2014) and Huq and Gilbert (2017), who state that factual knowledge about an entrepreneurial process should feature in a business school programme, but university education should transform students into active learners, thus allowing students to gain the facets of an entrepreneur holistically (Lautenschläger et al., 2011). Thus, the aim of this teaching was to offer the students an appreciation of how to be more valuable to the businesses that they will work for in the future, and not to educate them in how to start a business.

\section{Pedagogy for enterprise education}

The consideration of teaching methods relating to enterprise education (and the importance of enterprise education in general) is not a new field of study. In 1984 Jamieson (1984) carried out a review on enterprise education in schools. This review looked at the then current level of enterprise education offered to school students, noting in the main that enterprise education comprised of students engaging in work experience and in new startup ventures. This study continues to investigate attempts to integrate enterprise into the curriculum, and to move it past the traditional extra-curricular activities. Jamieson (1984) notes that this integration into the curriculum gives enterprise a validity and an importance in the view of the educator and the student, and that this makes experiential learning and reflection possible (Jamieson, 1984). This approach then results in the educator being the driver behind, and the owner of, the enterprise education (Jamieson, 1984). This means 
that levels of industry mentorship and industry integration can be reduced, in favour of a more traditional, didactic approach. Jamieson (1984) raises the point that asks what type of knowledge a student might need: subject knowledge, economics, practical wisdom? The research question stated by the authors concurs with this; whether the use of self-reflective teaching methodologies are valid for enterprise education? In response to this, Jamieson (1984) argues that traditional teachers might lack industrial or commercial experience, which may negatively influence their ability to consider what's required in enterprise education. Also, the lack of direct fit between traditional subject areas and enterprise education means educators will tend towards a skills-based learning experience (Jamieson 1984).

Similarly, when reviewing enterprise education pedagogy, Jones and Iredale (2010) note that a key differentiator between entrepreneurship and enterprise education lies in the pedagogical approach adopted. Entrepreneurship education might follow a didactic or direct approach whereas enterprise teaching might take a more creative approach (Jones and Iredale, 2010). In contrast, Arasti et al. (2012) note that the teaching methods of: group project; case study; individual project; development of a new venture creation project; and problem-solving are the five most appropriate teaching methods in business planning (without distinguishing between enterprise and entrepreneurship education). However, the lack of clarity regarding subject areas and educational phases is highlighted by Jones and Iredale (2010), who note that enterprise education pedagogy can be used across subject areas and over different phases of education, whereas entrepreneurship education is in the main delivered through business schools. This concurs with Ghandi's et al. (2016) review paper of a similar focus. However, Jones and Iredale (2010) also note that using creative, action and experiential learning pedagogies enables enterprise education to be applied in differing contexts, and the challenge for the educator is to create a learning environment which encourages learning by doing, mistake-making, problem solving et cetera.

\section{Enterprise teaching or entrepreneurship teaching}

The debate about the definitions and interchangeability of the terms enterprise and entrepreneurship continue today (QAA, 2018), where taught programmes use both terms liberally and with potential juxtaposition. A strong difference in terms is often debated by authors, yet many acknowledge a similarity in content, with a difference in context. Noting this, Jones et al. (2014) aim to open the debate on enterprise education and wish to establish 'enterprise' as a subject in its own right, as opposed to a sub-field of more traditional approaches: economics, strategic management et cetera. In recognition of the lack of clarity between terms, Jones et al. (2014) go on to note the similarities in entrepreneurship and enterprise education, and offer a unifying framework for education of such. Jones et al. (2014) continue to argue that enterprise education can be seen as the foundation of entrepreneurship education. However, it is clearly noted that the relationship between enterprise and entrepreneurship education is symbiotic, where knowledge, skills and attitudes developed in one area can develop similar in the other (Jones et al., 2014).

Embedding enterprise education in vocational disciplines could offer a way to create a cobenefiting system for the students. Keogh and Galloway's 2004 study discusses this further, noting that the terms enterprise and entrepreneurship are used interchangeably, and in this context entrepreneurship education is relevant to the students' pathway to professional chartered status. In this study it is noted that entrepreneurship education aims to increase the students' awareness and develop an understanding of new business creation; the theoretical aspects of what an entrepreneur is and does, why they do what they do, how they deal with business failure and success: these were all seen as vital for students studying an engineering programme (Keogh \& Galloway, 2004). In contrast, a study by Lee et al. (2018) showed that students who follow a business path have a different tendency to display entrepreneurial capabilities than students who follow an engineering path. The study suggests that targeted classes can therefore enhance the skills of particular student 
bodies (Lee et al., 2018). The study recommends that universities should increase the accessibility of entrepreneurship-based courses. Universities should also enhance the development of multidisciplinary curricula and provide settings for interdisciplinary collaborations to encourage students to be more proactive in a diverse learning scenario (Lee et al., 2018).

\section{Enterprise teaching methods}

When investigating pedagogical styles relating to entrepreneurship teaching (noting the interchangeability of the terms enterprise and entrepreneurship), tools for engaging cohorts is of key interest to those developing and utilising existing methods (Balan \& Metcalfe, 2012). Balan and Metcalfe (2012) reviewed tools for identifying teaching methods that are most likely to engage the cohort of students they were assessing. The review attempts to give educators a basis for identifying the most effective teaching method for entrepreneurship students when aiming to most likely achieve the learning outcomes. Balan and Metcalfe (2012) note that there is a wide range of views which are applicable, alongside a wide range of student profiles and student personal motivations, with some more applicable in certain situations than others. The review continues that stimulating creativity and the student and educator learning together, learning by doing, could provide the basis for selecting the most appropriate teaching methodology. It is highlighted that deep learning occurs when common learning objectives, student motivation, freedom to focus on the task, and an interaction between student and educator are present (Balan \& Metcalfe, 2012). Balan and Metcalfe (2012) concur with Tan and $\mathrm{Ng}$ (2006) in noting that the use of business plans in entrepreneurship teaching methodologies is seen as a major learning-by-doing component.

In contrast, Dochy et al. (2003) note a positive effect on the acquisition of knowledge and the skills to apply that knowledge from PBL; Gijbels et al. (2005) concur with this, stating $\mathrm{PBL}$ can target three categories of knowledge acquisition: understanding concepts, understanding of principles that link concepts, and linking of concepts and principles to conditions and procedures for application. PBL was noted by Boud and Falchicov (2007) to typically require students to identify the root problem which is designed to enhance their learning. Students then define their own objectives, plan the way forward and review the extent to which they reach their goals. The literature shows that the performance of students who learn using PBL is similar to those using 'traditional' methods, i.e. exams (Savery, 2015). However, it is also noted that the students who studied using PBL enjoyed the experience more than those that did not (Savery, 2015). Clegg and Bryan (2006) continue to note that PBL allowed core competencies to be focused on and taught which traditional methods did not. Moreover, by taking a holistic approach and focusing assessment on the learning outcomes, the assessment will complement the PBL and form a natural conclusion to it (Clegg and Bryan, 2006). Constructive alignment was noted by Biggs and Tang (2007) to be where learners use their own activity to construct knowledge, which is then assessed in ways which are aligned to what it is intended to be learned.

This concept of aligning educational theory to 'real-world' experience, where the educational frameworks of constructive alignment and authenticity are discussed, is most effective if instruction, learning and assessment are aligned, and students benefit when these are relevant to the subject matter; so in this context are relevant to entrepreneurial activity (Macht and Ball, 2006). Thus, the term 'authentic alignment' was used by Macht and Ball (2016) to describe this as a framework in which instruction, learning and assessment are aligned according to authenticity through resemblance and relevance to entrepreneurial activity.

Huq and Gilbert (2017) expand on this and debate the skills most identified by employers in the UK, US and Australia (communication; teamwork; critical thinking; problem solving; initiative \& enterprise; self-management and learning through technology) against the 
accepted ethos of what entrepreneurship education is trying to achieve (enabling an understanding of entrepreneurship; enhancing graduate employability and encouraging graduate enterprise). Hug and Gilbert (2017) argue that a 'one size fits all' approach cannot deliver these outputs, and learner-centred teaching strategies are required, which develop a sense of ownership on the part of the learner, and a learning community is established.

\section{Enterprise versus Entrepreneurship education in HEls}

The literature above shows that entrepreneurship education has its place, and for students wishing to start their own business, this type of education is valid. However, this paper argues that enterprise education also has its place, and this is currently under-represented in the education spectrum within UK universities at least.

Taking the QAA (2018) definitions:

- Enterprise: the generation and application of ideas, which are set within practical situations during a project or undertaking. This is a generic concept that can be applied across all areas of education and professional life.

- Entrepreneurship: the application of enterprise behaviours, attributes and competencies into the creation of cultural, social or economic value. This can, but does not exclusively, lead to venture creation.

The literature shows that only around $10 \%$ of students engage in start-up activities on completion of their studies (Jones \& Penaluna, 2013). Enterprise programs in HEls have traditionally focussed on start-ups as a key component of enterprise education (using the QAA definition of entrepreneurship) (QAA, 2018), however, this neglects the needs of the $90 \%$ of students that do not engage in start-up activities, who instead are entering more traditional business sectors. There is a need to broaden the enterprise offering to equip graduates with a range of skills that are more reflective of the increasingly competitive graduate job market they will enter (using the QAA definition of enterprise). In support of this, Rae (2007) argues that even though employability remains high on the agenda for $\mathrm{HEls}$, innovative practices to foster and enhance employability within universities remains a problematic area. Rae (2007) also notes that integrating employability and enterprise skills into a degree curriculum must be relevant to the core degree subject in order to engage the learner. By understanding how enterprise learning can offer enhanced outcomes in terms of personal and skills development, and then enhanced employability, indications show that learners will positively engage with enterprise opportunities. Finally, Rae et al. (2014) critically analysed the QAA report (QAA, 2012), and concluded that distinguishing between enterprise and entrepreneurship allows an enhanced understanding of learning outcomes; enterprise is a necessary precursor to entrepreneurship, without the basic building blocks of enterprise, business opportunities cannot readily be exploited; and external stakeholder engagement is required to ensure an authentic and context-based learning experience.

\section{Methodology}

This case-study methodology examines a defined data set within a specific context using a null hypothesis approach (Meyer et al., 2017). It explores a real-life context of enterprise teaching, and the effectiveness of that in enhancing the student experience (Yin, 2006, Zainal, 2007). This case study is an appropriate method to gain a fuller understanding of the outcomes of the teaching aims and learning objectives; the 'case' is the student cohort bodies, the related topics would include the teaching style and the way the taught content is made relevant to the student cohort bodies. Zainal (2007) discusses various categories of case study: exploratory, descriptive, explanatory, interpretive and evaluative, noting caution in viewing these categories in a hierarchical nature (Zainal, 2007). This study uses the exploratory case study methodology, as this study explores the phenomenon of using selfreflective teaching methodologies as the point of interest in the data set. The exploratory 
case study method is best applied when research addresses descriptive or explanatory questions and aims to produce a first-hand understanding of people and events Yin (2006). This case study uses theory development to challenge existing practices detailed in the literature within this paper, where entrepreneurship education is the default position; the authors use this case study to challenge the assumption that entrepreneurship education is the only way to engage students when enhancing their commercial awareness. The data sets presented represent the $p$ values in the null hypothesis testing theory, where a higher $p$ value would support a positive response to the research question of whether the use of self-reflective teaching methodologies are valid for enterprise education (Meyer et al., 2017).

This paper also reflects on the authors' use of self-reflective teaching methodologies (Hayward, 2000), where Hayward notes that through reflection, an educator can understand their teaching in a contextual setting which is dynamic, isolating and fast paced. During this study, the authors needed to adapt the teaching style to fit the educational background of the student body. The authors were required to reflect on the delivery of the taught material in order to engage the students, and amend that delivery to make the taught content relevant and engaging.

\section{The Taught Material}

Taught material was delivered in the second trimester of the academic years 2016-17 and 2017-18. The level 7 module, Bioscience with Enterprise, had 65 students in the 2016-17 cohort, comprising 31 Biomedical Science, 17 Biotechnology and 17 Drug Design and Delivery students respectively. The 2017-18 cohort had 59 students comprising 29 Biomedical Science, 15 Biotechnology and 15 Drug Design and Delivery students respectively. Module results are presented as class mean averages, and are anonymous and cannot be related to individuals. MEQ (module evaluation questionnaire) data was collected via a Blackboard survey, again with anonymous results. Response rates were $50 \%$ of the cohort. The MEQ surveys asked students to rate overall satisfaction on a scale of 'strongly agree / agree / disagree / strongly disagree' to areas associated to the module; this paper reviews feedback related to the Learning \& Teaching and the Overall Satisfaction areas as this aligns to the research question of the paper:

- How satisfied are you with the quality of the teaching?

- How engaging was this module for you?

- How satisfied are you overall with this module?

The level of engagement with the module aligns with Jamieson (1984) where the engaged educator becomes the driver behind, and the owner of, the enterprise education. Further to this, the level of satisfaction and engagement would be an indicator of the efficacy and appropriateness of that education, echoing Penaluna et al. (2012), Lautenschläger et al. (2011) and Mosly (2017).

Employability data was collected from DHLE data held at the University of Salford (HESA 2019).

Data was collected from sample populations from the two cohorts of MSc, level 7 students studying for degrees in Biomedical Science, Biotechnology and Drug Design and Delivery. Data was not collected from the cohorts of students studying MSc Environmental Management, MSc Leadership and Management Healthcare Practice, and MSc Leading Education Health and Social Care Reform. This was because the taught material for MSc Biomedical Science, Biotechnology and Drug Design and Delivery comprised a full programme, whereas the taught material for MSc Environmental Management, MSc Leadership and Management Healthcare Practice, and MSc Leading Education Health and Social Care Reform comprised single or double sessions only. 
The data collected is statistically analysed in this paper and therefore forms 2 years of comparable data.

\section{Results}

These results detail taught material delivered to one cohort of MSc, level 7 students studying for degrees in Biomedical Science, Biotechnology and Drug Design and Delivery, and to MSc level 7 students from areas including MSc Environmental Management, MSc Leadership and Management Healthcare Practice, and MSc Leading Education Health and Social Care Reform.

\section{Programme Development}

In 2016 a programme was formed to prepare students for the business environment, in the first instance with these students coming from MSc level 7 programmes in the in Biomedical Science, Biotechnology and Drug Design \& Delivery. Questions such as: how do I equip the students to better understand 'business'; what tools will the students need; what skills will the students require; will the students start their own business or work for an existing company? All of these were noted as the fundamental premise for the structure of the new module. From an initial start with two cohorts of Biomedical and Biotechnology students, an abbreviated offer of one or two sessions as opposed to a full module was established for delivery to students including level 7 students from areas including MSc Environmental Management, MSc Leadership and Management Healthcare Practice, and MSc Leading Education Health and Social Care Reform. Delivery of this taught content was done so within the relevant schools, not from the Business School; the location of an enterprise academic - actually in the school itself, means that the teaching differs from the traditional entrepreneurship education approach where delivery of the enterprise elements of a module would be offered by academics from an associated Business School, aligning to Jones and Iredale (2010). By embedding enterprise into the curriculum, industry engagement can be maximised, leading to the wider benefits of increased placements, work experience, collaborative research, consultancy opportunities et cetera. (Clarke and Davies, 2014, Clarke et al., 2015, Clarke and Ferry, 2017).

\section{Student feedback}

The students were requested to review the module they received in a post-delivery exercise. This feedback was collated and reviewed, and the main bullet point results detailed here. Initial assessment indicates that this method of delivery offers a coherent and co-operative approach as the course is bespoke and targeted (aligning to Jones et al., 2014). Data was collated from Module Evaluation Questionnaire (MEQ) questions and used to answer the research question; the use of the questionnaire and the structure of the questions allows a robust null hypothesis test of the research question, as the questions restricts bias and inflation of the hypothesis $p$ values, reducing the chance of false positives (Meyer et al., 2017).

The student results from the Biomedical Science, Biotechnology and Drug Design and Delivery students showed: 5 (of 65 ) business ( 8\%) plans worthy of funding; 1 student to proceed to developing intellectual property (IP) and engaging in further work to establish a viable business opportunity (aligning with Jones and Penaluna, 2013, Jones et al., 2014).

Student feedback included:

- a new idea to expand own thinking from scientific to business;

- alternate view not seen on a traditional syllabus;

- outside of the normal modules relating to science,

- a different perspective on business and industry; 
- could be applied at any management level;

- engaged my thinking in a different way;

- the ability to understand the business behind the science was very empowering.

Feedback showed $61 \%$ of students indicated very satisfied and $39 \%$ satisfied with the teaching and learning, 32\% of students indicated very engaged and $39 \%$ engaged, with $32 \%$ of students indicated very satisfied and $54 \%$ satisfied with the module overall.

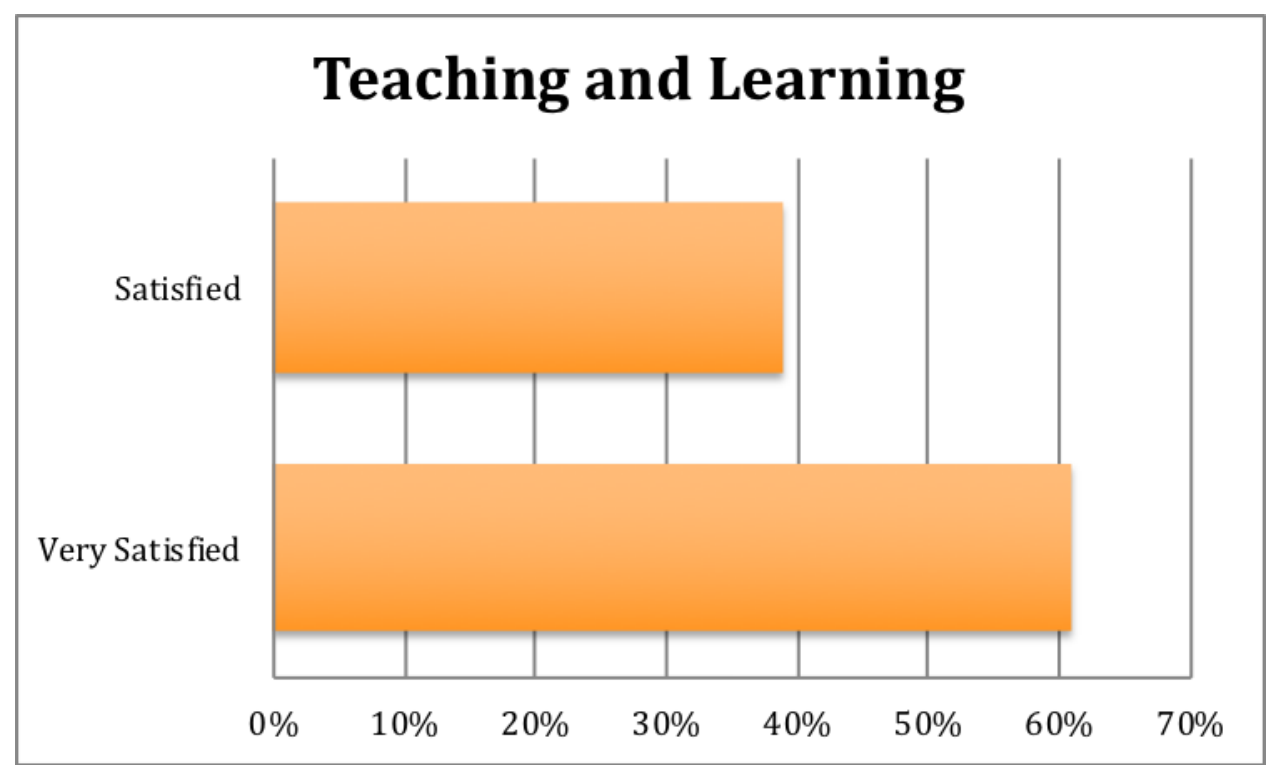

Fig 1. Feedback relating to Teaching and Learning

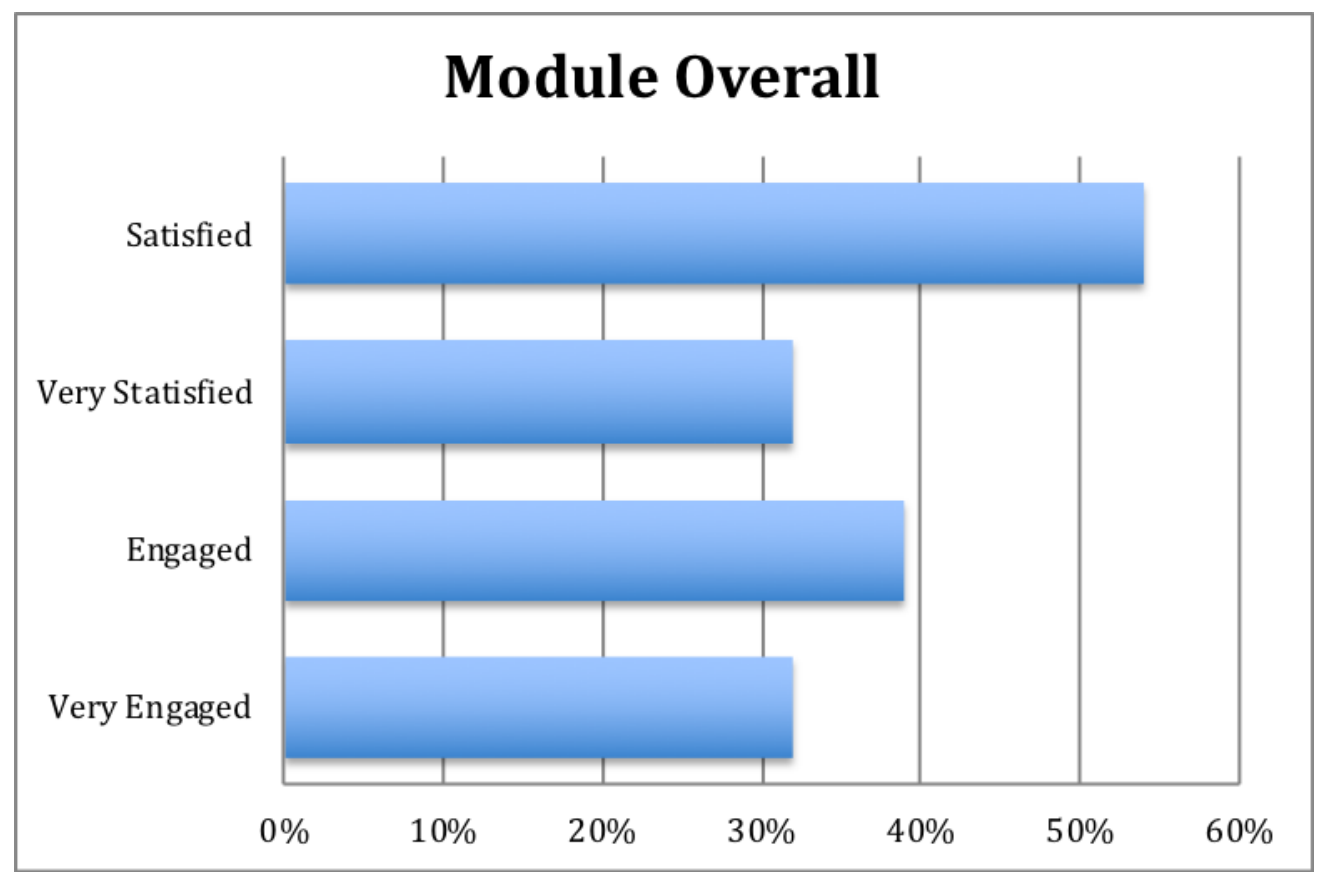

Fig 2. Feedback relating to the Module Overall 
For different cohorts over 2 years student feedback indicated a consistent satisfaction with the teaching of greater than $90 \%$, and a consistent satisfaction with the assessment of greater than $90 \%$. Student success was very high across 2 years; external examiners agreed that the task was appropriate for the level and that the high marks reflected the quality of the work.

\section{Student employability}

A single survey for all three MSc programmes was sent to University of Salford alumni in November 2017. Of the numbers sent, six responses were returned within one month. Responses were noted from graduates from cohorts representing 2012-2016/17; all three programmes (Biomedical Science, Biotechnology and Drug Design and Delivery) were represented in responses. Data from the survey showed $83.4 \%$ of alumni in full time employment or full-time study, and $16.7 \%$ seeking further training; employment was in science / technical roles or other professional roles such as senior executive and auditor.

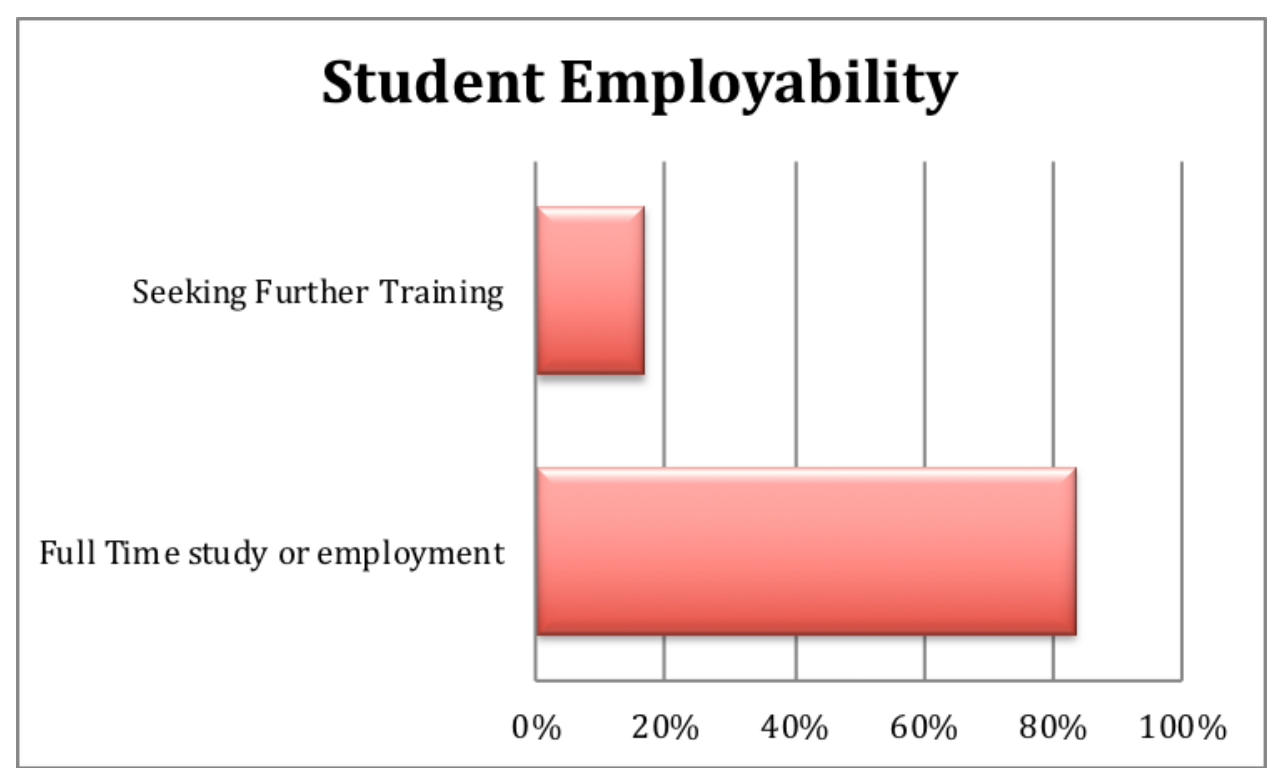

Fig 3. Feedback relating to Student Employability

One hundred per cent of alumni who returned the survey felt that their course prepared them very well $(33.3 \%)$ or well $(66.7 \%)$ for employment and $66.7 \%$ felt that their course prepared them very well for further study/ research, with $16.7 \%$ feeling well prepared and only $16.7 \%$ thinking the course left them not very well prepared for further study. 


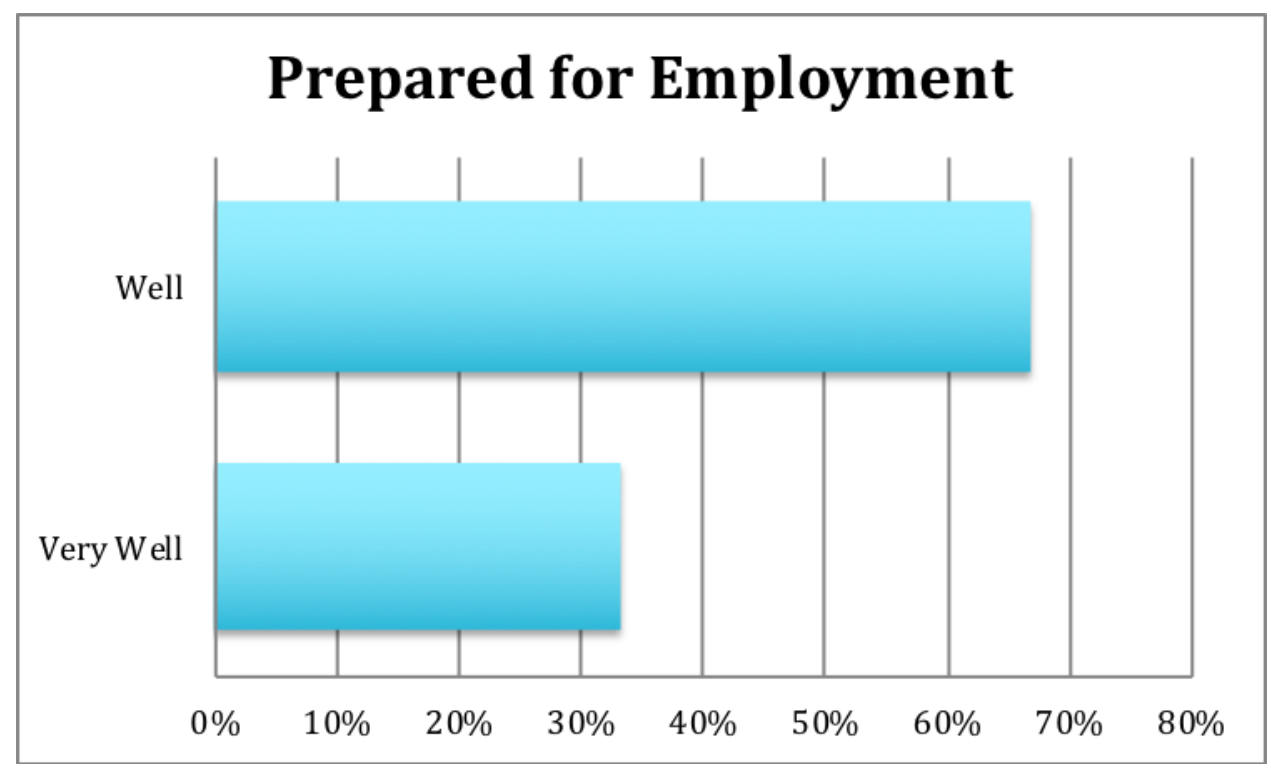

Fig 4. Feedback relating to Employment

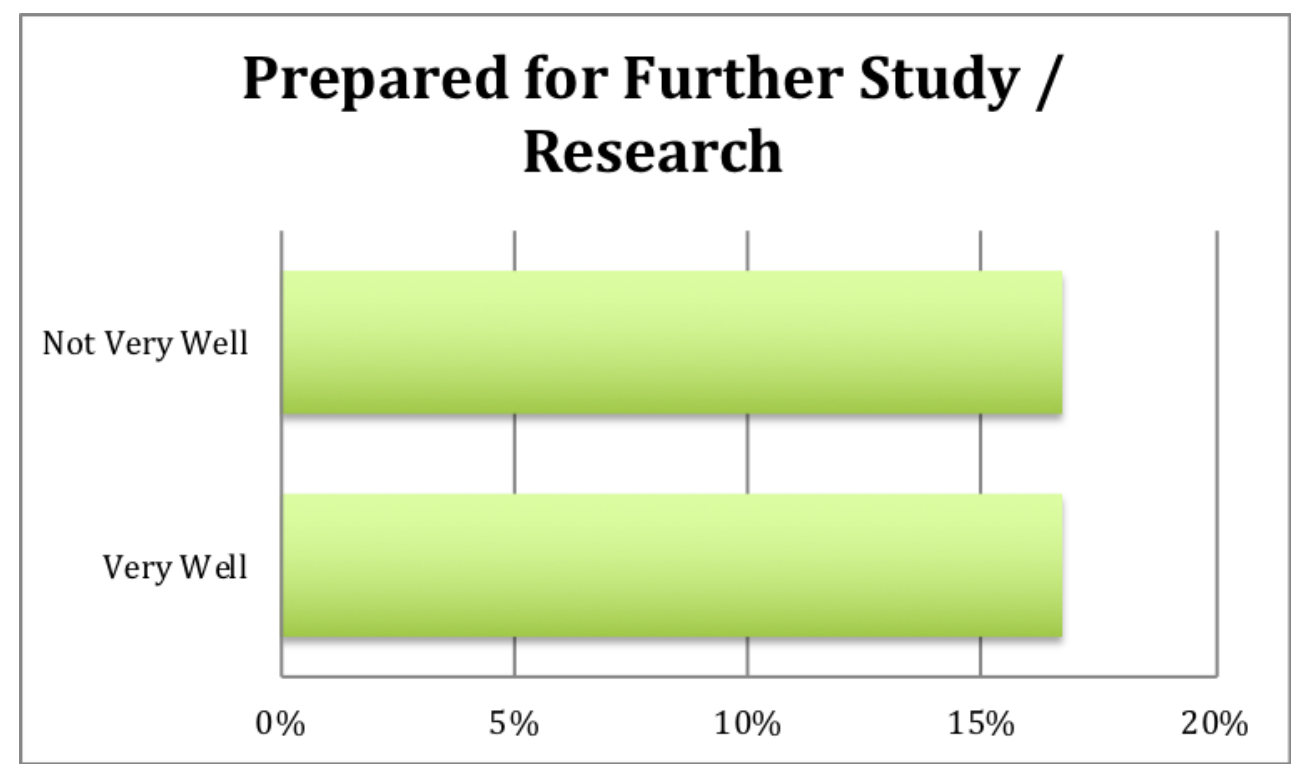

Fig 5. Feedback relating to Further Study / Research

$50 \%$ of respondents stated not at all when asked how prepared they felt for selfemployment or starting a business, with $16.7 \%$ unable to tell and $33.3 \%$ thinking the course prepared them very well. This appears to contradict the literature, however respondents span cohorts representing 2012-2016/17, with the Bioscience with Enterprise module running for cohorts 2016/17 and 2017/18, which only the most recent of alumni will have studied.

\section{Student engagement}

The students experienced fear and caution in the initial stages of receiving the taught material. This was in the main due to the fact that the students had experience of a science or related discipline, and many or all had no business background.

Due to initial confusion displayed by the students, the authors needed to reflect on the teaching style and the taught content; ensuring relevance was vital to realised student 
adoption and buy-in. This is reflected upon in the Discussion section of this paper. By reflecting on the teaching style, the authors were able to offer the taught material in a context which the students could relate to their own experience, and therefore engage with in an authentic manner, which concurs with Macht and Ball (2016).

\section{Discussion}

\section{Entrepreneurship teaching for students}

Jones and Penaluna (2013) state that only around $10 \%$ of students engage in start-up activities on completion of their studies; a straw poll of the students discussed in this paper was carried out asking how many students had thought about starting their own business. The results broadly aligned with the literature. The authors therefore carried out selfreflection with regards to the taught content (Hayward, 2000) and asked themselves the question, 'why teach students how to start a business?' as this will alienate $90 \%$ of students, reduce student satisfaction, and decrease student feedback. This module was structured to equip students to be more valuable to a business, not to start a business (Jones and Penaluna, 2013). The authors note that the skills and techniques required for both are similar; however the context within which they are acquired and understood is fundamentally different. The authors wanted the students to understand the role of cash in decision-making; reflect how their studies fit in an economic market; and develop an understanding of the drivers for businesses. To achieve this, the authors needed to ensure the students understood the relevance of the economy to degree discipline decision-making. The authors wanted to empower the student to be as good a graduate as a student studying a similar primary degree discipline at a comparable university, and also understand their degree discipline in the business context. This is therefore different to teaching science and engineering students how to start a business. This use of selfreflection allowed the authors to identify the gap in the current knowledge base with respect to enterprise teaching, offering a new scenario and aligning with Lautenschläger et al. (2011), Jones et al. (2012), Penaluna et al. (2012) and Ghandi et al. (2016).

The taught material was developed such that it was tailored to the context of the core subject being studied using PBL and authentic assessment, resulting in constructive alignment. In addition, the curriculum was co-created and co-delivered with industry contacts from relevant industry sectors. This structure concurs with current research (Jamieson, 1984, Clegg and Bryan, 2006, Boud and Falchicov, 2007, Watts et al., 2010, Balan and Metcalfe, 2012, Macht and Ball, 2016). By aligning the teaching methodologies, and by implementing PBL in the science context, the authors were able to demonstrate the appropriate nature of this style of enterprise education, aligning with Keogh and Galloway (2004), and Rae (2007).

\section{Module Delivery}

The module was delivered to one cohort of MSc, level 7 students studying for degrees in Biomedical Science, Biotechnology and Drug Design and Delivery. Sections of the module were also delivered to include MSc level 7 students from areas including MSc Environmental Management, MSc Leadership and Management Healthcare Practice, and MSc Leading Education Health and Social Care Reform.

The students as a whole noted that this style of teaching was novel to them; this presented a generic problem of ensuring the teaching content was relevant to the student, and that this relevance was directly communicated to the students to ensure student understanding. Initial results showed that students were confused by the content and lacked certainty in what was required of them. As the Biomedical Science, Biotechnology and Drug Design and Delivery students were also presented with formative and summative assessment, this raised concerns amongst the delivery academic staff around ensuring that the students were equipped with the skills and resources needed to effectively attempt the assessments 
presented to them. In a bid to 'understand what the students' didn't understand', the authors carried out an analysis of their own teaching methods, content and style, looking at who the customers are, what the customer channels are, how the market is segmented, and how those customers are engaged. It soon became clear that a different language would be advantageous, where the business terminology was translated into a science terminology, such that it was noted that science students are used to being able to replicate experiments in a laboratory setting. These students understand that if one is to apply a set of controlled variables in an experiment, one is able to accurately predict the results. This is not true in a business context, so the authors needed to find a way of presenting business uncertainty to an audience that is experienced in predictability; in other words, it is perfectly acceptable to predict an outcome. This aligns to the self-reflective practices noted by Hayward (2000), where Hayward states that through reflection, an educator can understand their teaching in a contextual setting which is dynamic, isolating and fast paced. The authors needed to adapt their teaching style in real-time, so within a lecture period, to maintain authenticity and relevance.

For example, relating back to the assessment structure, the authors discovered that asking the students to predict what will happen after Brexit, for instance, would yield confusion. However, asking the students what the probability of scenario a) or b) happening after Brexit would result in a useful discussion. The use of self-reflection and the simple understanding by the academic team to the style and language of the students in context gave an ability of the student to gain an enhanced understanding of the taught material, aligning with Macht and Ball (2016). This is echoed in the results where $32 \%$ of students indicated very engaged and $39 \%$ engaged with the module. Also, the authors found that the students faced confusion about what was expected of them. Students of this background are used to knowing that experiment a) should yield result b) if done correctly. By giving the students permission to speculate and reflect, and empowering the students to know that prediction of a business outcome can be a positive result, supposing reasonable assumptions are presented, resulted in the students having confidence to explore scenarios that they might previously have dismissed; this concurs with the literature (Lautenschläger and Haase, 2011, Lee et al., 2018) and is seen in the results where $61 \%$ of students indicated very satisfied and $39 \%$ satisfied with the teaching and learning. This resulted in the students feeling engaged and expanded their previously targeted thought process, and led to the students offering the student feedback responses noted.

For the students studying for the MSc Environmental Management, by adopting a selfreflective teaching approach (Hayward, 2000) the authors were able to maintain relevance for the student body and adapt the taught content to fit the context. By structuring discussions around the question 'does a company make environmental decisions based on the effect on the environment or the effect on the share price?', the authors were able to engage in enterprise education whilst maintaining a relevance to risk management. Similarly, for students studying for the MSc programmes in healthcare, the authors were able to offer enterprise education in context, where the discussion included end-user / customer identification, identification of the value proposition, and ways to enhance efficiencies and reduce costs.

The data show that the programme aligns with the literature and offers the students an enhanced level of preparation for employment, with $32 \%$ of students indicated very satisfied and $54 \%$ satisfied with the module overall. Verbal feedback from the students concurs with Jones and Penaluna (2013) who state that only around $10 \%$ of students engage in start-up activities on completion of their studies, and the assessment results of 5 out of 65 business plans being at a level of being suitable for funding development does align with the noted $10 \%$, with $8 \%$ agreement. 


\section{Implications}

A gap in the current knowledge base in enterprise education has been identified. Enterprise education structured in context with the aim of educating the student to be more valuable to a business, and not to start a business is discussed, and the research question stated by the authors: whether the use of self-reflective teaching methodologies are valid for enterprise education has been investigated using a null hypothesis test (Meyer et al., 2017). The data shows that these results align to the literature (Jones and Penaluna, 2013); approximately $90 \%$ of students wished to go into employment and $10 \%$ had considered starting their own business. This paper shows that although the skills required are similar, they are acquired and understood in a different context. The research question has been investigated and has been shown to be valid.

\section{For the University}

A novel approach to enterprise teaching with the use of self-reflective teaching methodologies has been developed at a UK university, focusing on teaching non-business students how to be more valuable to a business within their degree subject context. The effectiveness of this teaching methodology has been investigated using MEQ student feedback data. Results show that this has empowered the students with an enhanced understanding of commercial issues and increased employability (Rae 2007, Huq and Gilbert, 2017). This has also led to enhanced relationships with industry and given students a wider understanding of their degree area. The research data discussed in this paper shows a high rate for alumni who went on to full time employment or full time study $(83.4 \%)$, with a strong response for how the alumni felt when asked how the course prepared them for employment (33.3\% indicated very well and $66.6 \%$ indicated well). Additionally $66.7 \%$ felt that their course prepared them very well for further study/ research, with $16.7 \%$ feeling well prepared and only $16.7 \%$ thinking the course left them not very well prepared for further study.

\section{For the educator}

The use of self-reflective teaching methodologies (Hayward, 2000) are noted to be vital in order to deliver enterprise education in a way that is relevant to the student cohort body. By reflecting on one's teaching style and delivery method, the authors were able to engage non-business students in enterprise education, and receive a high level of student satisfaction; feedback showed $61 \%$ of students indicated very satisfied and $39 \%$ satisfied with the teaching and learning. It is noted that self-reflection was a valuable process for delivery to each degree discipline. By employing PBL and self-reflective teaching methodologies, an increased synergy between the business taught elements and the science subjects was created, which resulted in feedback showing $32 \%$ of students indicating very engaged and $39 \%$ engaged. Initial feedback suggests that the students appreciated the introduction of enterprise into their course and in the main did not view it as disjointed or irrelevant to their wider aims, where $32 \%$ of students indicated very satisfied and $54 \%$ satisfied with the module overall. More so, the students commented favourably towards the integration of enterprise into their primary discipline, and noted an enhanced learning experience because of this integration (Penaluna et al., 2012, Lautenschläger et al., 2011 and Mosly, 2017). The results indicate that the students have an enhanced understanding of commercial issues and increased employability (Rae 2007, Huq and Gilbert, 2017); the enhanced relationships with industry included in the taught material offer students a wider commercial understanding of their degree area.

\section{Conclusions}

This paper shows how the use of self-reflective teaching methodologies in enterprise education can offer a high level of student satisfaction in non-business students. This paper 
has shown how self-reflection allows the educator to tailor delivery of the taught material to ensure relevance to the student cohort in each subject context. A case study was undertaken to evaluate the use of these self-reflection methodologies, and results suggest that the students appreciated the introduction of enterprise into their course and in the main did not view it as disjointed or irrelevant to their wider aims. More so, the students commented favourably towards the integration of enterprise into their primary discipline, and noted an enhanced learning experience because of this integration.

This paper showed that the approach of self-reflection has empowered the students with an enhanced understanding of commercial issues and increased employability (Rae 2007, Huq and Gilbert, 2017). This has also led to enhanced relationships with industry and given students a wider understanding of their degree area.

\section{References}

Alberti, F., Sciascia, S., \& Poli, A. (2004). Entrepreneurship education: notes on an ongoing debate, presented at the 14th Annual IntEnt Conference, July, Naples, Italy, available at https://www.academia.edu/29140921/Entrepreneurship Education Notes on an Ongoing Debate (accessed 25 May 2020)

Arasti, Z., Falavarjani, M. K., \& Imanipour, N. (2012). A study of teaching methods in entrepreneurship education for graduate students. Higher Education Studies, Vol. 2 No. 1, p.2.

Balan, P., \& Metcalfe, M. (2012). Identifying teaching methods that engage entrepreneurship students. Education + Training, Vol. 54 No. 5, pp368-384.

Biggs, J., \& Tang, C. (2007). Teaching for Quality Learning at University (3rd edn) Buckingham: SRHE and Open University Press.

Boud, D., \& Falchikov, N. (Eds.). (2007). Rethinking assessment in higher education: Learning for the longer term. Routledge.

Bray, R., \& Boon, S. (2011). Towards a framework for research career development: An evaluation of the UK's Vitae Researcher Development Framework. International Journal for Researcher Development, Vol. 2 No. 2, pp99-116.

Clarke A.P. \& Davies J. (2014). Academic involvement in the delivery of Continuous Professional Development: why should they bother?, paper presented at the Institute of Small Business and Entrepreneurship Conference, 05-06 Nov, Manchester, U.K.

Clarke A.P., Flanagan J. and Davies J. (2015). An investigation into the drivers for the delivery of academic consultancy services, paper presented at the Institute of Small Business and Entrepreneurship Conference, 11-12 Nov, Glasgow, U.K.

Clarke A.P., Deacon, J.C., McAdam R., Davies J., \& Flanagan J. (2016). LUCID: a relationship window to enhance university / industry knowledge exchange, paper presented at the Engage HEl Conference, Engaged Scholarship: impact, policy and practice, 19-20 May, Preston, U.K.

Clarke, A.P. \& Ferry, N. (2017). Science Enterprise: a case study, paper presented at the Engage HEl Conference, Engaged Scholarship: impact and practice, 15-16 May, Salford, U.K. 
Clegg, K., \& Bryan, C. (2006). 20 Reflections, rationales and realities. Innovative assessment in higher education, p.216.

Dochy, F., Segers, M., Van den Bossche, P., \& Gijbels, D. (2003). Effects of problem-based learning: A meta-analysis. Learning and instruction, Vol 13 No. 5, pp.533-568.

European Commission. (2010). Europe 2020: A strategy for smart, sustainable and inclusive growth: Communication from the commission. Publications Office of the European Union.

European Commission (2018). Proposal for a Council Recommendation on Key Competences for LifeLong Learning. Publications Office of the European Union.

Fayolle, A., Gailly, B., \& Lassas-Clerc, N. (2006). Assessing the impact of entrepreneurship education programmes: a new methodology. Journal of European Industrial Training, Vol. 30 No. 9, pp.701-720.

Galloway, L., \& Brown, W. (2002). Entrepreneurship education at university: a driver in the creation of high growth firms?. Education + Training, Vol. 44 No. 8/9, pp.398-405.

Gandhi, S., Jimmy, M. B., \& Taghazadeh, S. (2016). A comprehensive review of entrepreneurship course offering in engineering programs. In Proceedings.

Gijbels, D., Dochy, F., Van den Bossche, P., \& Segers, M. (2005). Effects of problem-based learning: A meta-analysis from the angle of assessment. Review of educational research, Vol. 75 No. 1, pp.27-61.

Hayward, L. M. (2000). Becoming a self-reflective teacher: A meaningful research process. Journal of Physical Therapy Education, Vo. 14 No. 1, p.21.

HESA. (2019). Higher Education Student Data, available at: https://www.hesa.ac.uk/dataand-analysis/students (accessed 14 June 2019).

Huq, A., \& Gilbert, D. (2017). All the world's a stage: transforming entrepreneurship education through design thinking. Education + Training, Vol. 59 No. 2, pp.155-170.

Jamieson, I. (1984), "Schools and enterprise", in A. Watts and P. Moran (Eds.), Education for Enterprise, Cambridge: Ballinger.

Jones, B., \& Iredale, N. (2010). Enterprise education as pedagogy. Education + training, Vol. 52 No. 1, pp.7-19.

Jones, C., \& Penaluna, A. (2013). Moving beyond the business plan in enterprise education. Education + Training, Vol. 55 No. 8/9, pp.804-814.

Jones, C., Matlay, H., \& Maritz, A. (2012). Enterprise education: for all, or just some?. Education + Training, Vol. 54 No. 8/9, pp.813-824.

Jones, C., Matlay, H., Penaluna, K., \& Penaluna, A. (2014). Claiming the future of enterprise education. Education + Training, Vol. 56 No. 8/9, pp.764-775.

Keogh, W., \& Galloway, L. (2004). Teaching enterprise in vocational disciplines: reflecting on positive experience. Management Decision, Vol. 42 No.3/4, pp.531-541. 
Lautenschläger, A., \& Haase, H. (2011). The myth of entrepreneurship education: seven arguments against teaching business creation at universities. Journal of Entrepreneurship Education, Vol. 14 No. 1, pp.147-161.

Lee, Y., Kreiser, P. M., Wrede, A. H., \& Kogelen, S. (2018). University-Based Education and the Formation of Entrepreneurial Capabilities. Entrepreneurship Education and Pedagogy, Vol. 1 No. 4, pp.304-329.

Macht, S. A., \& Ball, S. (2016). "Authentic Alignment"-a new framework of entrepreneurship education. Education + Training, Vol. 58 No. 9, pp.926-944.

Matlay, H. and Carey, C. (2007). Entrepreneurship education in the UK: a longitudinal perspective, Journal of Small Business and Enterprise Development, Vol. 14 No. 2, pp.25263.

McKeown., J., Millman, C., Sursani, S.R., Smith, K. and Martin, L.M. (2006) Graduate entrepreneurship education in the United Kingdom, Education + Training, Vol. 48, pp.597613.

Meyer, K. E., Van Witteloostuijn, A., \& Beugelsdijk, S. (2017). What's in a p? Reassessing best practices for conducting and reporting hypothesis-testing research. Journal of International Business Studies, Vol. 48, pp. 535-551

Mosly, I. (2017). The Significance of Including an Entrepreneurship Course in Engineering Programs. Higher Education Studies, Vol .7 No. 4, p.9.

Mwasalwiba, E. S. (2010). Entrepreneurship education: a review of its objectives, teaching methods, and impact indicators. Education + Training, Vol. 52 No. 1, pp.20-47.

Penaluna, K., Penaluna, A., \& Jones, C. (2012). The context of enterprise education: insights into current practices. Industry and Higher Education, Vol. 26 No. 3, pp.163-175.

Pollard, E., Hirsh, W., Williams, M., Jonathan, B., Marvell, R., Tassinari, A., ... \& Ball, C. (2015). Understanding employers' graduate recruitment and selection practices. BIS Research Paper 231.

QAA (2018). Enterprise and Entrepreneurship Education: Guidance for UK Higher Education Providers

Rae, D. (2007). Connecting enterprise and graduate employability: challenges to the higher education culture and curriculum?. Education + Training, Vol. 49 No.8/9, pp.605-619.

Rae, D. and Matlay, H. (2010). Enterprise Education and University Entrepreneurship, Industry and Higher Education, Vol. 24 No.6, p..409-411.

Rae, D., Matlay, H., McGowan, P., \& Penaluna, A. (2014). Freedom or prescription: the case for curriculum guidance in enterprise and entrepreneurship education. Industry and Higher Education, Vol. 28 No. 6, pp.387-398.

San Tan, S., \& Ng, C. F. (2006). A problem-based learning approach to entrepreneurship education. Education + Training, Vol. 48 No. 6, pp.416-428.

Savery, J. R. (2015). Overview of problem-based learning: Definitions and distinctions. Essential Readings in Problem-Based Learning: Exploring and Extending the Legacy of Howard S. Barrows, Vol 9, pp.5-15. 
Vitae (2010), Researcher Development Framework, available at: www.vitae.ac.uk/ CMS/files/upload/Vitae-Researcher-Development-Framework.pdf (accessed 30 July 2019).

Watts, C., Wray, K., Kennedy, C., Freeman, P., \& Trainer, G. (2010). Embedding enterprise in biosciences: added value for employability. Industry and Higher Education, Vol. 24 No. 6, pp.487-494.

Williams, M., Tassinari, A., \& Ball, C. (2015). Understanding employers' graduate recruitment and selection practices-Evidence report.

Yin, R. K. (2006). Case study methods. Handbook of complementary methods in education research, Vol 3, pp.111-122.

Young, D. I. (2014). Enterprise for all: the relevance of enterprise in education.

Zainal, Z. (2007). Case study as a research method. Jurnal Kemanusiaan, Vol. 5 No.1. 